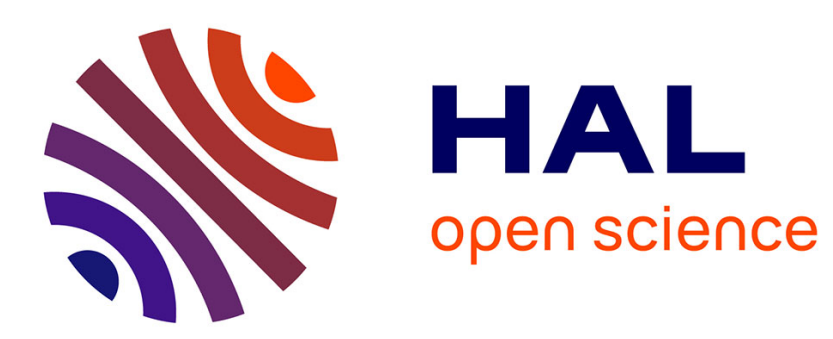

\title{
Kinetic and thermodynamic studies of the dissolution of thoria-urania solid solutions
}

\author{
G. Heisbourg, S. Hubert, N. Dacheux, J. Purans
}

\section{To cite this version:}

G. Heisbourg, S. Hubert, N. Dacheux, J. Purans. Kinetic and thermodynamic studies of the dissolution of thoria-urania solid solutions. Journal of Nuclear Materials, 2004, 335, pp.5-13. in2p3-00023266

HAL Id: in2p3-00023266

https://hal.in2p3.fr/in2p3-00023266

Submitted on 3 Nov 2004

HAL is a multi-disciplinary open access archive for the deposit and dissemination of scientific research documents, whether they are published or not. The documents may come from teaching and research institutions in France or abroad, or from public or private research centers.
L'archive ouverte pluridisciplinaire HAL, est destinée au dépôt et à la diffusion de documents scientifiques de niveau recherche, publiés ou non, émanant des établissements d'enseignement et de recherche français ou étrangers, des laboratoires publics ou privés. 


\title{
Kinetic and thermodynamic studies of the dissolution of thoria- urania solid solutions
}

\author{
G. Heisbourg, S. Hubert*, N. Dacheux, J. Purans** \\ Institut de Physique Nucléaire, Université Paris- Sud, F- 91406 Orsay, France
}

\begin{abstract}
The dissolution of $\mathrm{Th}_{1-\mathrm{x}} \mathrm{U}_{\mathrm{x}} \mathrm{O}_{2}$ was investigated through leaching experiments combined with $\mathrm{X}$ ray Photoelectron Spectroscopy (XPS) and X- ray Absorption Spectroscopy (XAS) analyses. These experiments were performed in acidic and in oxidizing conditions (nitric solutions), for several compositions of solid solutions ranging from $\mathrm{x}=0.24$ to $\mathrm{x}=0.81$. Static sequential experiments in acidic media performed at room temperature confirmed that higher concentration of uranium in the solid solution leads to higher release of uranium in the leachate whatever the $\mathrm{pH}$. The normalized dissolution rate in oxidizing media is increasing all the more the content of uranium is increases in the mixed oxide. While for Th enriched solids, kinetic parameters remain similar to that of $\mathrm{ThO}_{2}$, in the case of uranium enriched solids, a drastic change is observed, and kinetic parameters are similar to that of $\mathrm{UO}_{2}$ ones. For $\mathrm{x}>0.50$, the saturation is reached in the leachate after 100 days. XPS and EXAFS analysis on leached samples pointed out an oxidation of $\mathrm{U}(\mathrm{IV})$ at the surface for $\mathrm{x}<0.5$, and in the bulk for $x>0.5$. Enrichment in Th is also observed at the surface of the solid, indicating the formation of a protective layer of hydrated thorium oxide, or hydroxide.

Finally, the solubility product of secondary phase was determined. The values obtained are in good agreement with that of $\mathrm{ThO}_{2}, \mathrm{Th}(\mathrm{OH})_{4}$ and $\mathrm{ThO}_{2}, \mathrm{xH}_{2} \mathrm{O}$ reported in the literature.
\end{abstract}

Keywords: leaching, thorium, uranium, oxide, dissolution, solubility

\footnotetext{
*Corresponding author: shubert @ipno.in2p3.fr

** on leave from University of Riga (Institut de physique des solides) (Lettonie)
} 


\section{Kinetic and thermodynamic studies of the dissolution of \\ thoria- urania solid solutions}

\section{Introduction}

Thoria based fuel reactors are considered as a potential advanced fuel for Generation IV nuclear energy systems. One of the main interest of thoria as a nuclear fuel is the production of lower amounts of minor actinides [1], its potential of burning weapons plutonium [2], its high capability to resist to aqueous corrosion [3, 4], and its isomorphism with other tetravalent actinide dioxides. Because of its very low solubility, the direct disposal of spent fuel in deep geological repository is considered. Therefore, thoria is generally mixed with other actinide oxide, since fissile isotopes such as ${ }^{233} \mathrm{U},{ }^{235} \mathrm{U}$ or ${ }^{239} \mathrm{Pu}$ are needed to ignite the nuclear reaction in reactor. Also, to assess the concept of direct disposal of irradiated nuclear fuel, it is important to predict the rate of the radionuclides release from the fuel, and to characterize the secondary phase formed at saturation of the leachate. Because of the low normalized dissolution rates of thoria, leaching experiments were performed in corrosive media, i.e. acidic and oxidizing media in order to accelerate the dissolution reactions. Dissolution experiments were undertaken on $\mathrm{Th}_{1-\mathrm{x}} \mathrm{U}_{\mathrm{x}} \mathrm{O}_{2}$ solid solutions with several mole ratios $\mathrm{U} / \mathrm{U}+$ Th ranging from $\mathrm{x}=0.24$ up to 0.81 . $\mathrm{Up}$ to now, there has been only few studies on the dissolution of $(\mathrm{Th}, \mathrm{U}) \mathrm{O}_{2}$ mixed oxide $[5,6,7,8]$. In these papers, mostly kinetics of dissolution are discussed. The leaching behaviour of $\mathrm{Th}_{1-\mathrm{x}} \mathrm{U}_{\mathrm{x}} \mathrm{O}_{2}$ with $\mathrm{x}=0.24$ and 0.37 has been previously discussed [8], showing that, in nitric solution, an increase of the normalized dissolution rate is observed when increasing the $U$ amount in the solid solution, indicating the presence of U(VI) at the surface of the sample before the detachment of the surface complex. However, after 2 years of leaching experiments, no thermodynamic equilibrium was observed and only kinetics of dissolution could be obtained.

This paper presents the results of leaching experiments of a large composition of $\mathrm{Th}_{1-\mathrm{x}} \mathrm{U}_{\mathrm{x}} \mathrm{O}_{2}$ solid solutions with $\mathrm{x}$ values varying from 0.37 to 0.81 in oxidizing conditions (nitric media) combined with surface and sample analysis of leached samples, by using X-ray Photoelectron Spectroscopy and X ray Absorption Spectroscopy (EXAFS). The analysis of secondary phase controlling the concentration of thorium in the leachate after saturation of the solution will be discussed taking into account the determination of the solubility products of secondary phase and the characterization of the surface of leached samples. 


\section{Experimental}

\subsection{Synthesis of $\operatorname{Th}_{1-x} U_{x} O_{2}$}

Solid solutions of thorium-uranium (IV) dioxide were prepared by using wet chemistry method from a mixture of concentrated thorium chloride (1.0 M), uranium (IV) chloride $(0.7 \mathrm{M})$ and oxalic acid solutions following the method already described [8]. The precipitate was first dried then heated in a PYROX furnace at $500^{\circ} \mathrm{C}$ under inert atmosphere for 2 hours then at $1300^{\circ} \mathrm{C}$ under reducing conditions $\left(\mathrm{Ar}-10 \% \mathrm{H}_{2}\right.$ gas) for 10 hours with heating rate of $2-5^{\circ} \mathrm{C} \cdot \mathrm{min}^{-1}$. Several compositions of thorium-uranium (IV) dioxide solid solutions were prepared using this procedure with starting mole ratios $\mathrm{U} /(\mathrm{U}+\mathrm{Th})=0.25,0.35,0.50,0.65$, and 0.80 .

\subsection{Characterization of the samples}

The final composition of each solid solution was determined by using PIXE analysis (Particle Induced X-ray Emission) and EPMA (Electron Probe Micro Analysis), leading respectively to the final composition of $\mathrm{x}=0.24,0.37,0.53,0.67$, and 0.81 . All the samples were characterized by X-ray diffraction using a Philips PW 1050/70 diffractometer $\left(\mathrm{Cu} \mathrm{K}_{\alpha}\right.$ rays, $\lambda=1.5418 \AA$ ). The analysis of the XRD pattern obtained for the five compositions of solid solutions yielded to lattice parameter values already described [7]. They were in good agreement with the theoretical lattice parameter value assuming that each fluorite type phase $\mathrm{ThO}_{2}$ and $\mathrm{UO}_{2}$ contributes to the resulting lattice parameter proportionally to their concentration in the material [9-11].

The specific surface area of all the samples was determined with a Coulter SA 3100 apparatus, using nitrogen adsorption (BET method). While for the pure powdered thorium dioxide, a degassing was carried out at $120^{\circ} \mathrm{C}$ during $300 \mathrm{~min}$, it was performed at $70^{\circ} \mathrm{C}$ for 600 min for $\mathrm{Th}_{1-\mathrm{x}} \mathrm{U}_{\mathrm{x}} \mathrm{O}_{2}$ solid solutions in order to avoid any oxidation of tetravalent uranium into uranyl species. The specific surface area measured for all the samples were 1.3, 0.9, 1.1, 0.8 and $0.7 \mathrm{~g} . \mathrm{m}^{-2}$ for $\mathrm{x}=0.24,0.37,0.51,0.67$ and 0.81 , respectively.

\subsection{Leaching experiments}

Static batch experiments were performed on powdered samples at room temperature, using high density polyethylene (HDPE) containers $\left(\right.$ Nalgene $\left.{ }^{\mathrm{TM}}\right)$. The experiments were performed in 
nitric media with the same leaching procedure described elsewhere [8]. For each test, $15 \mathrm{~mL}$ of solution were mixed with the solid in the $\mathrm{S} / \mathrm{V}$ ratio close to $200 \mathrm{~cm}^{-1}$ for leaching times up to 800 days. The $\mathrm{pH}$ of the electrolyte was adjusted with $0.1 \mathrm{M} \mathrm{HNO}_{3}$ (or $0.1 \mathrm{M} \mathrm{KNO}_{3}$ ) in order to keep the ionic strength constant $(\mathrm{I}=0.1 \mathrm{M})$ except for experiments in $1 \mathrm{M}$ and $5 \mathrm{M} \mathrm{HNO}_{3}$. The separation of both phases was obtained by centrifugation at $13000 \mathrm{rpm}$ to avoid the presence of colloids with size larger than $11 \mathrm{~nm}$. The solutions were analyzed for the concentration of Th and U using either Inductively Coupled Plasma - Mass Spectroscopy (ICPMS Fisons Plasma Quad) or $\alpha$-liquid scintillation technique (PERALS: Photon Electron Rejecting Alpha Liquid Scintillation Spectrometry). For ICP- MS experiments, 1 ppb of terbium and bismuth were added to the samples as internal standards.

\subsection{X-ray photoelectron spectroscopy}

Photoelectron spectroscopy studies were performed using a multidetection electron analyzer (VSW HA 150, Fixed Analyser Transmission (FAT) mode). XPS spectra were excited by the $\mathrm{Mg} \mathrm{K}_{\alpha} \mathrm{X}$-ray source at $1253.6 \mathrm{eV}$ (generated by operating the anode at $15 \mathrm{kV}$ and $10 \mathrm{~mA}$ ). The combined resolution of the lectron spectrometer and line width was $0.2 \mathrm{eV}$.

XPS was used to analyze the surface of the samples before and after leaching. High resolution spectra were recorded for $\mathrm{C}_{1 \mathrm{~s}}, \mathrm{O}_{1 \mathrm{~s}}, \mathrm{Th}_{4 \mathrm{f}}$, and $\mathrm{U}_{4 \mathrm{f}}$ core levels. The binding energy of the $\mathrm{C}_{1 \mathrm{~s}}$ level from contamination $(284.6 \pm 0.1 \mathrm{eV})$ was used as an internal reference for calibrating each spectrum when charging effects were observed. The spectral features of the $\mathrm{U}_{4 \mathrm{f}}$ core levels lines (spin-orbit splitting $4 \mathrm{f}_{5 / 2}$ and $4 \mathrm{f}_{7 / 2}$ ) are very sensitive to probe the chemical state of the uranium atoms. Each peak can be assumed to contain two components namely U (IV) and U (VI) which appear at different energies, the latter one at higher binding energy, and for which satellites are also associated. The line width of each component was fixed at $2.2 \mathrm{eV}$ with a distribution of $85 \%$ of lorentzian and $15 \%$ of gaussian. The spin-orbit coupling (distances between $\mathrm{U}^{4} \mathrm{f}_{7 / 2}$ and $\mathrm{U}_{4} \mathrm{f}_{5 / 2}$ peaks) and the surface ratio between both contributions was fixed respectively at $10.8 \mathrm{eV}$ and 0.75 . The satellite peak of $U$ (IV) was respectively fixed at $7.4 \mathrm{eV}$ in the highest energy in good agreement with that reported by G.Allen et al [12]. The intensity of satellite peaks was considered to be ten times weaker than the main peaks.

A standard integral background was substracted and the intensities were obtained by fitting the peaks to gaussian- lorentzian peaks using the constant energy separation of the two components $(10.8 \mathrm{eV})$. XPSPeak 3.0 was used for performing the analysis of the XPS spectra. 
The $4 \mathrm{f}_{5 / 2}$ peak was deconvoluted into 3 components centered at $387.6 \pm 0.2 \mathrm{eV}$ (satellite), 391.0 $\pm 0.2 \mathrm{eV}(\mathrm{U}(\mathrm{IV}))$ and $392.1 \pm 0.2 \mathrm{eV}(\mathrm{U}(\mathrm{VI}))$, while the $4 \mathrm{f}_{7 / 2}$ was deconvoluted in 2 components located at $380.2 \pm 0.2 \mathrm{eV}(\mathrm{U}(\mathrm{IV}))$ and $381.3 \pm 0.2 \mathrm{eV}(\mathrm{U}(\mathrm{VI}))$. The ratio of the peak areas was used to calculate the ratio of the 2 uranium oxidation states present onto the surface. Figure 1 shows an example of a deconvolution of XPS spectra in the $\mathrm{U}_{4 \mathrm{f}}$ region obtained for $\mathrm{Th}_{0.47} \mathrm{U}_{0.53} \mathrm{O}_{2}$ before leaching. From the analysis of the $\mathrm{U}_{4} \mathrm{f}_{7 / 2}$, the relative amount of $\mathrm{U}(\mathrm{VI}) / \mathrm{U}$ at the surface of all samples was evaluated roughly between 9 and $20 \%$.

The spectrum for the $\mathrm{O}_{1 \mathrm{~s}}$ peak obtained for the same sample is presented in Figure 2. All spectra are identical to that of $\mathrm{ThO}_{2}$, and other compositions of solid solutions. The $\mathrm{O}_{1 \mathrm{~s}}$ band obtained for three compositions of solid solutions before leaching, suggests that most of the intensity of the band arises from the oxide $\left(\mathrm{O}^{2-}\right)$ moieties from a peak located at $529.8 \mathrm{eV}$. The weak shoulder observed in the high binding energy side arises from the hydroxyl oxygen, and $\mathrm{H}_{2} \mathrm{O}$ moieties contribution (absorbed water) present at the surface [13]. The $\mathrm{O}_{1 \text { s }}$ peak was deconvoluted into 3 components, centered at $529.5 \pm 0.2 \mathrm{eV}$ (corresponding to the $\mathrm{O}^{2-}$ component), at $531.5 \pm 0.2 \mathrm{eV}$ (corresponding to oxygen engaged in $\mathrm{O}-\mathrm{H}$ binding), and at $533.0 \pm 0.2 \mathrm{eV}$ (corresponding to oxygen of $\mathrm{H}_{2} \mathrm{O}$ ). The line width of each component was fixed at $2.2 \mathrm{eV}$ (60\% of lorentzian and $40 \%$ of gaussian). The deconvolution of the $\mathrm{O}_{1 \mathrm{~s}}$ peaks shows that the fraction of the $\mathrm{OH}$ and $\mathrm{H}_{2} \mathrm{O}$ species is very weak, whatever the composition of the solid solutions considered.

\subsection{X-ray absorption spectroscopy}

EXAFS data were measured at the synchrotron radiation Beamline (ROBL BM-20) at ESRF (Grenoble) using a Si (111) double-crystal monochromator.

The experiments were performed on sintered pellets of $\mathrm{ThO}_{2}, \mathrm{Th}_{0.75} \mathrm{U}_{0.25} \mathrm{O}_{2}, \mathrm{Th}_{0.5} \mathrm{U}_{0.5} \mathrm{O}_{2}$ before and after leaching at $\mathrm{pH}=1$ and $\mathrm{pH}=11$. The surface of each pellet was scratched in order to get powder coming from the surface layer. $14 \mathrm{mg}$ of dried powder were diluted in $100 \mathrm{mg}$ of cellulose in order to obtain pellets which were sealed with Kapton tape. Reference powders of $\mathrm{ThO}_{2}, \mathrm{UO}_{2}$ and $\mathrm{U}_{3} \mathrm{O}_{8}$ were used. The resulting $\mathrm{U}$ cross section yields an edge jump between 0.05 and 0.1 for the $\mathrm{U}-\mathrm{L}_{\mathrm{III}}$ absorption edge at $17166 \mathrm{eV}$, and Th- $\mathrm{L}_{\mathrm{III}}$ absorption edge at $16300 \mathrm{eV}$. For energy calibration of the sample spectra, the spectrum from an yttrium foil and $\mathrm{Pb}$ foil was recorded for $\mathrm{U}$ and $\mathrm{Th}$, respectively.

The EXAFS spectra were collected in transmission at room temperature. Three scans were collected from each sample then averaged. The EXAFS data analysis was carried out with 
standard methods using our software package "EDA" [11]. The MS calculations were performed by FEFF8 code.

\section{Results and discussion}

\subsection{Leaching of $\mathrm{Th}_{1-x} \mathrm{U}_{x} \mathrm{O}_{2}$ solid solutions in nitric media}

The leaching experiments were performed on $\mathrm{Th}_{1-x} \mathrm{U}_{x} \mathrm{O}_{2}$ solid solutions with $x=0.24,0.37$, $0.53,0.67$, and 0.81 in several nitric solutions between $\mathrm{pH}=1$ and $\mathrm{pH}=3(\mathrm{I}=0.1 \mathrm{M})$ and in $1 \mathrm{M}$ and $5 \mathrm{M} \mathrm{HNO}_{3}$. The evolution of the dissolved mass of thorium and uranium for some compositions of solid solutions is reported in Figure 3 with several concentrations of nitric acid, up to 800 days. The normalized dissolution rate increases all the more since the thorium substitution by uranium rate is increasing. For $x<0.5$, the evolution of the normalized mass loss is linear for 25 days whatever the $\mathrm{pH}$ considered. This behaviour is typical of surface controlled mechanism [8]. However, for $x>0.5$, the normalized mass loss is drastically higher compared to that obtained for $x<0.5$ in the same conditions of leaching. Moreover, after 100 days of leaching, the normalized dissolution rate decreases to reach a quasi plateau. Therefore both actinides are released congruently in solutions for $\mathrm{pH}<3$, while for higher $\mathrm{pH}$ values, the Th concentration in the leachate is close to the detection limit indicating the quantitative precipitation of thorium. Figure 4 shows the variation of the normalized mass loss with leaching time square root for $\mathrm{Th}_{0.19} \mathrm{U}_{0.81} \mathrm{O}_{2}$. As can be seen, the variation of $\mathrm{N}_{\mathrm{L}}=\mathrm{f}\left(\mathrm{t}^{1 / 2}\right)$ seems to be linear for $\mathrm{Th}_{0.33} \mathrm{U}_{0.67} \mathrm{O}_{2}$ and $\mathrm{Th}_{0.19} \mathrm{U}_{0.81} \mathrm{O}_{2}$ solid solutions, which indicates that diffusion mechanism occurs through a thin film layer probably formed by the precipitation of secondary phase.

\subsection{Kinetic study of the dissolution}

In acidic media, the experimental normalized dissolution rate values obtained for the solid solutions at constant ionic strength were found to be proportional to a fractional power of the proton activity as follows:

$$
\mathrm{R}_{\mathrm{H}}=k_{T}^{\prime}\left(\gamma_{\mathrm{H} 3 \mathrm{O}}^{+}\left[\mathrm{H}_{3} \mathrm{O}^{+}\right]\right)^{\mathrm{n}}=k_{T, I}^{\prime}\left[\mathrm{H}_{3} \mathrm{O}^{+}\right]^{\mathrm{n}}
$$

where $\mathrm{R}_{\mathrm{H}}$ refers to the proton-promoted normalized dissolution rate and $\mathrm{k}_{298 \mathrm{~K}}$ (expressed in g. $\mathrm{m}^{-2} \cdot \mathrm{d}^{-1}$ ) represents the apparent normalized dissolution rate constant at $\mathrm{pH}=0, n$ is the partial 
order related to the proton concentration and $\gamma_{\mathrm{H}_{3} \mathrm{O}^{+}}$corresponds to the proton activity coefficient. The values obtained for the partial order and the apparent normalized dissolution rate constant for $\mathrm{ThO}_{2}, \mathrm{Th}_{0.76} \mathrm{U}_{0.24} \mathrm{O}_{2}$ and $\mathrm{Th}_{0.63} \mathrm{U}_{0.37} \mathrm{O}_{2}$ were already published [8]. While for thorium enriched solid solutions, the dissolution rate was determined between 50 and 800 days, for uranium enriched solid solutions, it was calculated before 80 days. The variation of $\log$ $\left(\mathrm{R}_{\mathrm{H}(\mathrm{U})}\right)$ versus $\log$ a $\left(\mathrm{H}_{3} \mathrm{O}^{+}\right)$for $x=0.53,0.67,0.81$ and $\mathrm{UO}_{2}$ is presented in Figure 5. The kinetic law is verified between $10^{-1} \mathrm{M}$ and $10^{-4} \mathrm{M} \mathrm{HNO}_{3}$. However, contrary to enriched thorium samples where the partial order is about 0.3 , the partial order is larger than 1 for uranium enriched samples. This could indicate that two chemical reaction steps involving protons, occur: oxidation of $\mathrm{U}(\mathrm{IV})$ in $\mathrm{U}(\mathrm{VI})$ with faster oxidation reaction then detachment of activated complexes formed with U(VI) and U(IV). The values obtained for the kinetic law parameters are gathered in Table 1 and compared with that obtained for thorium enriched samples. From this table, a drastic change is observed in the dissolution behaviour for uranium enriched solid solutions $(x>0.5)$. The values of the apparent normalized dissolution rate constant $\mathrm{k}^{\prime}{ }_{298 \mathrm{~K}}$ increases significantly with the uranium mole loading, however a drastic change is observed for $x>0.5$. While for $x<0.5$, the values of the rate constant are only one to two orders of magnitude larger than that reported for $\mathrm{ThO}_{2}$, it becomes four to five orders of magnitude higher for $x>0.5$, and close to that of $\mathrm{UO}_{2}$. From the experimental results, as already mentioned by Casas et al [15], the mechanism goes through the oxidation of U (IV) followed by the release of U(VI) from the surface. The dissolution rate is then controlled by the relative magnitude of both reactions rates $\mathrm{R}_{\mathrm{ox}}$ and $\mathrm{R}_{\mathrm{H}}$. For thorium enriched solid solutions, the partial order of $\mathrm{Th}$ is close that of $\mathrm{ThO}_{2}$. Then, the dissolution behaviour is quite similar to that of $\mathrm{ThO}_{2}$, and prevents the uranium from oxidation. It seems that the presence of large amounts of Th compared to uranium in the solid solution act as inhibitor stabilizing uranium in its tetravalent state. In the case of enriched uranium solid solutions, the dissolution behaviour is similar to that of pure $\mathrm{UO}_{2}$ in oxidative conditions as already described in [15]. Then the oxidation rate $\mathrm{U}(\mathrm{IV})-\mathrm{U}(\mathrm{VI})$ becomes faster, compared to that of the dissolution reaction, which can explain the modification of the partial order.

\subsection{Characterization of leached samples by EXAFS}

Extended X-ray Absorption Fine Structure (EXAFS) and X-ray Absorption Near-Edge (XANES) Spectroscopy are standard techniques providing information on the oxidation state 
and the local environment of actinide. Recently, the local structure of $\mathrm{ThO}_{2}-\mathrm{UO}_{2}$ solid solutions has been established for the first time [11]. The EXAFS and XANES of $\mathrm{Th}_{0.76} \mathrm{U}_{0.24} \mathrm{O}_{2}$ and $\mathrm{Th}_{0.47} \mathrm{U}_{0.53} \mathrm{O}_{2}$ solid solutions leached at $\mathrm{pH}=1$ and $\mathrm{pH}=11$ in $\mathrm{HNO}_{3}$ were recorded to determine the local environment and the oxidation state of uranium and were compared to that of $\mathrm{UO}_{2}$ and $\mathrm{U}_{3} \mathrm{O}_{8}$ references. Figure 6 displays the XANES data for the uranium $\mathrm{L}_{\mathrm{III}}$-edge for both solid solutions leached at $\mathrm{pH}=1$. This figure shows that a small change of the XANES spectra at the $\mathrm{U} \mathrm{L}_{\mathrm{III}}$-edge is observed for $\mathrm{Th}_{0.76} \mathrm{U}_{0.24} \mathrm{O}_{2}$ leached at $\mathrm{pH}=1$, which suggests that the uranium oxidation occurs only at the surface of the leached sample (see also XPS data), while for $\mathrm{Th}_{0.47} \mathrm{U}_{0.53} \mathrm{O}_{2}$ leached at $\mathrm{pH}$ 1, a strong change is observed at the $\mathrm{U} \mathrm{L}_{\mathrm{III}}$-edge. Correlatively, the XANES spectrum is close to that recorded for $\mathrm{U}_{3} \mathrm{O}_{8}$. It corresponds to the oxidation of uranium (IV) (reference $\mathrm{UO}_{2}$ ) into uranium (VI) (reference $\mathrm{U}_{3} \mathrm{O}_{8}$ ) in the bulk sample as well at the surface (see XPS data).

The EXAFS analysis shows strong modification of the local structure in the first coordination shell of uranium. The different ionic radii of $\mathrm{U}^{4+}$ and $\mathrm{U}^{6+}$ and consequently different $\mathrm{U}-\mathrm{O}$ distances give strong beating in the EXAFS and respectively two peaks in the Fourier transform (Figure 7). At the same time, the XANES at the $\mathrm{Th} \mathrm{L}_{\mathrm{III}}$ edge is not so sensitive to the leaching procedure. For $\mathrm{Th}_{0.47} \mathrm{U}_{0.53} \mathrm{O}_{2}$ leached at $\mathrm{pH}=11$ (Fig. 7), we observed a small change of the XANES at the $\mathrm{U} \mathrm{L}_{\mathrm{III}}$-edge, which corresponds to the small oxidation of uranium in the bulk sample. The EXAFS analysis shows the increase of the disorder in the local structure. These results are in a good agreement with the study on the kinetics of dissolution of $\mathrm{ThO}_{2}-\mathrm{UO}_{2}$ systems leached at $\mathrm{pH}=1$. Therefore, it confirms the change in the mechanism of dissolution for $\mathrm{x}=0.53$.

However, no secondary phase was observed at the surface of the leached samples in transmission and fluorescence modes. Only XAFS measurements in a nearly grazing incidence configuration would allow a favoured characterization of minor secondary phases if it differs from the original structure.

\subsection{Characterization of the surface of leached samples by XPS}

All the compositions of solid solutions were characterized by using XPS after two years of leaching time and compared with the unleached samples. High resolution spectra were recorded for $\mathrm{C}_{1 \mathrm{~s}}, \mathrm{O}_{1 \mathrm{~s}}, \mathrm{Th}_{4 \mathrm{f}}$ and $\mathrm{U}_{4 \mathrm{f}}$ to determine their chemical state of these elements. By comparison with the raw materials, the analysis of the $\mathrm{O}_{1 \mathrm{~s}}$ bands on the leached samples shows that the 
fraction of the $\mathrm{OH}$ and $\mathrm{H}_{2} \mathrm{O}$ species is all the more higher than the Th substitution by uranium increases. In the case of $\mathrm{Th}_{0.76} \mathrm{U}_{0.24} \mathrm{O}_{2}$, the $\mathrm{OH}$ component increases in the leached sample, and the $\mathrm{H}_{2} \mathrm{O}$ species, which were weak in the reference, increases significantly. For $\mathrm{Th}_{0.47} \mathrm{U}_{0.53} \mathrm{O}_{2}$, the same behaviour was found to be more pronounced. For $\mathrm{Th}_{0.19} \mathrm{U}_{0.81} \mathrm{O}_{2}$, the $\mathrm{H}_{2} \mathrm{O}$ component becomes preponderant (see Figure 8).

In the $4 \mathrm{f}$ - region, the XPS spectra of leached samples exhibit some modifications compared to the raw samples. For $\mathrm{Th}_{0.76} \mathrm{U}_{0.24} \mathrm{O}_{2}$, a small contribution of $\mathrm{U}$ (VI) is observed in the spectra, while for $\mathrm{Th}_{0.47} \mathrm{U}_{0.53} \mathrm{O}_{2}$, a shift of the peak due to the oxidation of uranium (IV) at the surface during leaching tests is observed. In the case of $\mathrm{Th}_{0.19} \mathrm{U}_{0.81} \mathrm{O}_{2}$, the contribution of $\mathrm{U}$ (VI) becomes preponderant at the surface of the leached sample. Figures 9 shows an example of the $\mathrm{U}-4 \mathrm{f}_{7 / 2}$ spectra obtained for leached $\mathrm{Th}_{0.19} \mathrm{U}_{0.81} \mathrm{O}_{2}$. The $\mathrm{U}(\mathrm{VI}) / \mathrm{U}$ mole ratios determined by XPS analysis, before and after leaching are summarized in Table 2.

From XPS spectra recorded in the Th $-4 \mathrm{f}$ region, no significant change is observed. All the spectra are similar to that observed for $\mathrm{ThO}_{2}$. However, for leached samples for which a thermodynamic equilibrium is reached after saturation, a change of the value of the peak ratio related to Th and $\mathrm{U}$ is observed by comparison with the initial composition. Table 3 represents the mole ratio $\mathrm{Th} / \mathrm{U}$ before and after leaching for several compositions of solid solutions. Even if the relative amount of Th and $U$ at the surface is not very accurate by XPS, the results are consistent to that determined by PIXE. This analysis reveals that after leaching, the surface of the solid solutions is thorium enriched all the more the Th substitution rate is higher. This indicates that the dissolution is not kinetically controlled and that its precipitation occurs in the leaching conditions. The secondary phase is expected to be hydrated thorium oxide or thorium hydroxide which forms a protective layer at the surface of the grain.

\section{Thermodynamic study of the solid solutions dissolution}

As mentioned above, for uranium enriched solid solutions, such as $\mathrm{Th}_{0.33} \mathrm{U}_{0.67} \mathrm{O}_{2}$ and $\mathrm{Th}_{0.19} \mathrm{U}_{0.81} \mathrm{O}_{2}$ leached in $10^{-1} \mathrm{M}, 10^{-2} \mathrm{M}$, and $10^{-3} \mathrm{M} \mathrm{HNO}_{3}$ or for $\mathrm{Th}_{0.76} \mathrm{U}_{0.24} \mathrm{O}_{2}$ leached in $10^{-4} \mathrm{M}$ $\mathrm{HNO}_{3}$, two dissolution steps were observed on the dissolution curves: a linear increase of the actinide mass loss typical of kinetically controlled dissolution, followed by the setting of a plateau after about 100 days. In the case of $\mathrm{Th}_{1-\mathrm{x}} \mathrm{U}_{\mathrm{x}} \mathrm{O}_{2}$ leached in $10^{-3} \mathrm{M}$ and $10^{-4} \mathrm{M} \mathrm{HNO}_{3}$, the uranium mass loss reaches a plateau, while the thorium mass loss is close to the detection limit indicating the quantitative precipitation of the thorium precipitation (Figure 3). This second step is thermodynamically controlled by the precipitation of $\mathrm{ThO}_{2}, \mathrm{nH}_{2} \mathrm{O}$ and/or $\mathrm{Th}(\mathrm{OH})_{4}$ 
depending on the $\mathrm{pH}$ conditions. Then, the dissolution of the solid is blocked as soon as the thorium precipitation occurs which is consistent with the XPS experiments which confirms that Th phase forms a protective layer at the surface of the grains.

\subsection{Solubility products of secondary phase}

The solubility constant of secondary phases was determined in several leaching conditions from the thorium concentration in the leachate at saturation. The values obtained for several compositions of solid solutions and for different $\mathrm{pH}$ values are gathered in Table 4. The comparison of the values obtained between our experimental data and that reported in the literature confirms that in $10^{-1} \mathrm{M} \mathrm{HNO}_{3}$, the precipitates can be ascribed as crystalline $\mathrm{ThO}_{2}$ while in $10^{-4} \mathrm{M} \mathrm{HNO}_{3}$, and are mainly due to amorphous $\mathrm{Th}(\mathrm{OH})_{4}$. For intermediate leachate concentration, precipitate can be ascribed by the general formulation $\operatorname{ThO}_{\mathrm{n}}(\mathrm{OH})_{4-2 \mathrm{n}} \cdot \mathrm{xH}_{2} \mathrm{O}$ corresponding to amorphous $\mathrm{Th}(\mathrm{OH})_{4}, \mathrm{ThO}_{2} \cdot \mathrm{xH}_{2} \mathrm{O}$ or $\mathrm{ThO}_{2}$ (hydrated) [17]. Our values are in good agreement with the values obtained by Neck et al [18] and Rai et al.[19].

\section{Conclusion}

The dissolution of $\mathrm{Th}_{1-\mathrm{x}} \mathrm{U}_{\mathrm{x}} \mathrm{O}_{2}$ was systematically studied in oxidizing and corrosive media, versus the uranium content and versus the concentration of nitrate ions in the leachate at a fixed ionic strength. Depending on the uranium content, and the $\mathrm{pH}$ of the leachate, the dissolution curve involves one or two successive steps.

For mixed oxides where Th is preponderant and nitric concentration less than $10^{-3} \mathrm{M}$, the dissolution is only kinetically controlled during 3 years of leaching time, until Th precipitates for $\mathrm{pH}>2$. The normalized dissolution rates are determined from the linear evolution of the normalized leaching then, the parameters describing the kinetic law can be determined. In this case, the parameters remain similar to that already obtained for $\mathrm{ThO}_{2}$. The normalized dissolution rate constants of solid solutions are one or two orders of magnitude larger, due to the slow oxidation of U (IV) at the surface of the samples.

For uranium enriched solid solutions, two dissolution steps are observed. The first one is kinetically controlled during the first 100 days of leaching while the second one corresponds to the thermodynamic equilibrium. A drastic increase of the dissolution parameters point out a fast oxidation of U(IV) leading to a faster release rate of a final oxidized solid. The partial order becomes larger than 1 and close to that obtained for $\mathrm{UO}_{2}$, while the normalized dissolution rate 
constants are roughly 5 to 6 orders of magnitude larger than that of $\mathrm{ThO}_{2}$ and similar to that of $\mathrm{UO}_{2}$. The characterization of leached samples shows the oxidation of the uranium in the bulk for $U$ enriched samples.

The second step controlling the dissolution of solid solutions is thermodynamically controlled since it is due to the formation of thorium enriched secondary phase. It is observed for leaching time exceeding 100 days for U-enriched samples in $10^{-2} \mathrm{M}$ and $10^{-3} \mathrm{M} \mathrm{HNO}_{3}$ and in $10^{-4} \mathrm{M}$ $\mathrm{HNO}_{3}$ for $\mathrm{Th}_{0.74} \mathrm{U}_{0.24} \mathrm{O}_{2}$.

The XPS analysis of the leached solids ( $\mathrm{t}=800$ days) underlines thorium enrichment at the surface. The thorium concentration in the leachate is thus controlled by the precipitation of thorium phase.

From the thorium concentration determined at the saturation, the solubility products were determined for several compositions of solid solutions and for several $\mathrm{pH}$ values. The experimental values are in good agreement with the values reported in the literature for $\mathrm{Th}(\mathrm{OH})_{4}, \mathrm{ThO}_{2}$ and $\mathrm{ThO}_{2} \cdot \mathrm{nH}_{2} \mathrm{O}$. The precipitate forms a protective layer at the surface of the solid, and slows down or blocks the uranium release from the solid. Thus, the dissolution process corresponds then to a diffusion process through the thorium phase layer.

\section{Acknowledgments:}

The authors wish to thank J. Lambert (LCPME- UMR 6764, CNRS- Université H. PoincaréNancyI) for providing XPS spectra, G. Lagarde for PIXE analysis at the Laboratoire du Musée du Louvre, J. Ritt from the Institut de Radioprotection et de Sûreté Nucléaire (IRSN -Fontenay aux Roses) and C. Hennig from ESRF (Grenoble) to give us the possibility to use respectively the ICP-MS equipment, and ROBL line for EXAFS measurements respectively. 


\section{References}

[1] B. Fourest, S. Hubert, G. Lagarde, T. Vincent "Thorium as a waste management option: Residual Risk of Final Disposal" Project report Nuclear Science and technology, edited by H. Gruppelaar, J. P. Schapira EUR19142 (2000)

[2] H. T. Akie, T. Muromura, H. Takano, S. Matsuura, Nucl. Tech. 107 (1994) 182

[3] B. Fourest, T. Vincent, G. Lagarde, S. Hubert, P. Baudoin, J. Nucl.Mat.282 (2000) 180

[4] S. Hubert, K. Barthelet, B. Fourest, G. Lagarde, N. Dacheux, N. Baglan, J. Nucl.Mat. 97 (2001) 206

[5] R. W. Dyck, R. Taylor, D. G. Boase, dissolution of $(\mathrm{Th}, \mathrm{U}) \mathrm{O}_{2}$ in nitric acid hydrofluoric acid solutions, Atomic Energy of Canada Limited Report, AECL-5957 (1977)

[6] S. Sunder, N. H. Miller, J. Nucl. Mat 279 (2000)118

[7] G. Heisbourg, C. Fauvel, N. Dacheux, G. Lagarde, J. Ritt, S. Hubert, Proc. of the International conference ICEM'01, Bruges, , “ Radioactive waste management and environmental remediation" ASME 2001

[8] G. Heisbourg, S. Hubert, N. Dacheux, J. Ritt, J. Nucl. Mat. 321 (2003) 141

[9] I. Cohen, R.M. Berman, J. Nucl. Mat, 18 (1966) 77

[10] K. Bakker, E.H.P. Cordfunke, R.J.M. Konings, R.P.C. Schram, J. Nucl. Mat. 250 (1997) 1

[11] J. Purans, G. Heisbourg, N. Dacheux, Ph. Moisy, S. Hubert, to be published in Physica Scripta (2004)

[12] G. C. Allen, N. R. Holmes, J. of Chem. Soc., X-ray Photoelectron Spectroscopy of the uranium/oxygen System, 1985

[13] S. Guilbert, M. J. Guittet, N. Barré, M. Gautier-Soyer, P. Trocellier, D. Gosset, Z. Andriambolona, J. Nucl. Mat. 282 (2000) 75

[14] J.C. Mikkelsen and J.B. Boyce, Phys. Rev. B 15 (1983) 7130

[15] I. Casas, J. Gimenez, V. Marti, M. E. Torrero and J. De Pablo, Radiochim. Acta 66 (1994) 23

[16] V. Neck, V. Mueller, R. Bouby, M. Altmaier, J. Rothe, M. A. Denecke, J. I. Kim, Radiochim. Acta, 90 (2002) 485

[17] V. Neck, M. Altmaier, R. Müller, A. Bauer, Th. Fanghanel, J. I. Kim, Radiochim.Acta, 91 (2003) 253

[18] J. L. Ryan, D. Rai, Inorg. Chem. 26 (1987) 4140

[19] D. Rai, M. Yui, D. A. Moore, J. of Sol. Chem. 32 (2003) 1 


\section{Tables}

Table I: Kinetic parameters of $\mathrm{Th}_{1-\mathrm{x}} \mathrm{U}_{\mathrm{x}} \mathrm{O}_{2}$ dissolution

\begin{tabular}{|c|c|c|}
\hline Samples & $\mathrm{n}$ & $\mathrm{k}_{\mathrm{T}, \mathrm{I}}\left(\mathrm{g} . \mathrm{m}^{-2} \cdot \mathrm{d}^{-1}\right)$ \\
\hline $\mathrm{ThO}_{2}$ & $0.26 \pm 0.05$ & $(8.2 \pm 1.2) 10^{-8}$ \\
\hline $\mathrm{Th}_{0.76} \mathrm{U}_{0.24} \mathrm{O}_{2}$ & $0.34 \pm 0.02$ & $(4.1 \pm 0.5) 10^{-6}$ \\
\hline $\mathrm{Th}_{0.63} \mathrm{U}_{0.37} \mathrm{O}_{2}$ & $0.30 \pm 0.01$ & $(1.6 \pm 0.5) 10^{-5}$ \\
\hline $\mathrm{Th}_{0.47} \mathrm{U}_{0.53} \mathrm{O}_{2}$ & $1.30 \pm 0.08$ & $(6 \pm 1) 10^{-2}$ \\
\hline $\mathrm{Th}_{0.33} \mathrm{U}_{0.67} \mathrm{O}_{2}$ & $1.13 \pm 0.03$ & $(2.3 \pm 0.1) 10^{-1}$ \\
\hline $\mathrm{Th}_{0.19} \mathrm{U}_{0.81} \mathrm{O}_{2}$ & $1.50 \pm 0.1$ & $2.9 \pm 1.5$ \\
\hline $\mathrm{UO}_{2}$ & $0.91 \pm 0.09$ & $(4 \pm 1.6) 10^{-1}$ \\
\hline
\end{tabular}

Table 2: Uranium (IV) amount at the surface of $\mathrm{Th}_{1-\mathrm{x}} \mathrm{U}_{\mathrm{x}} \mathrm{O}_{2}$ before and after leaching in $10^{-1} \mathrm{M} \mathrm{HNO}_{3}$

\begin{tabular}{|c|c|c|}
\hline Samples & $\mathrm{U}(\mathrm{VI}) / \mathrm{U}$ & conditions \\
\hline \multirow{2}{*}{$\mathrm{Th}_{0.76} \mathrm{U}_{0.24} \mathrm{O}_{2}$} & $9 \%$ & unleached \\
& $21 \%$ & leached \\
\hline \multirow{2}{*}{$\mathrm{Th}_{0.63} \mathrm{U}_{0.37} \mathrm{O}_{2}$} & $20 \%$ & unleached \\
& $32 \%$ & leached \\
\hline \multirow{2}{*}{$\mathrm{Th}_{0.47} \mathrm{U}_{0.53} \mathrm{O}_{2}$} & $15 \%$ & unleached \\
\hline \multirow{2}{*}{$\mathrm{Th}_{0.33} \mathrm{U}_{0.67} \mathrm{O}_{2}$} & $30 \%$ & leached \\
\hline \multirow{2}{*}{$\mathrm{Th}_{0.19} \mathrm{U}_{0.81} \mathrm{O}_{2}$} & $13 \%$ & unleached \\
& $14 \%$ & leached \\
\hline
\end{tabular}

Table 3: $\mathrm{Th} / \mathrm{Th}+\mathrm{U}$ mole ratio at the surface of the $T \mathrm{Th}_{1-\mathrm{x}} \mathrm{U}_{\mathrm{x}} \mathrm{O}_{2}$ samples before and after leaching

\begin{tabular}{|c|c|c|c|c|}
\hline Samples & $\begin{array}{c}\mathrm{Th} / \mathrm{U}+\mathrm{Th} \\
\text { before leaching } \\
\text { (PIXE) }\end{array}$ & $\begin{array}{c}\mathrm{Th} / \mathrm{U}+\mathrm{Th} \\
\text { before leaching } \\
\text { (XPS) }\end{array}$ & $\begin{array}{c}\mathrm{Th} / \mathrm{U}+\mathrm{Th} \\
\text { after leaching } \\
\text { (XPS) }\end{array}$ & $\begin{array}{c}\text { Leaching } \\
\text { conditions }\end{array}$ \\
\hline $\mathrm{Th}_{0.76} \mathrm{U}_{0.24} \mathrm{O}_{2}$ & $76 \%$ & $78 \%$ & $87 \%$ & $10^{-4} \mathrm{M} \mathrm{HNO}_{3}$ \\
\hline $\mathrm{Th}_{0.33} \mathrm{U}_{0.67} \mathrm{O}_{2}$ & $33 \%$ & $35 \%$ & $\begin{array}{l}62 \% \\
59 \%\end{array}$ & $\begin{array}{c}10^{-3} \mathrm{M} \mathrm{HNO}_{3} \\
10^{-1} \mathrm{M} \mathrm{HNO}_{3}\end{array}$ \\
\hline $\mathrm{Th}_{0.19} \mathrm{U}_{0.81} \mathrm{O}_{2}$ & $19 \%$ & $24 \%$ & $\begin{array}{l}50 \% \\
46 \%\end{array}$ & $\begin{array}{l}10^{-3} \mathrm{M} \mathrm{HNO}_{3} \\
10^{-1} \mathrm{M} \mathrm{HNO}_{3}\end{array}$ \\
\hline
\end{tabular}


Table 4: Solubility products of secondary phase

\begin{tabular}{|c|c|c|c|c|c|c|}
\hline Sample & {$\left[\mathrm{HNO}_{3}\right]$} & $\begin{array}{l}\text { Log Ksp } \\
(\mathrm{I}=0.1 \mathrm{M})\end{array}$ & $\log \mathrm{K}_{\mathrm{sp}}^{0}$ & Secondary phase & $\begin{array}{c}\log \mathrm{K}_{\mathrm{sp}}^{0} \\
\text { (literature) }\end{array}$ & Ref \\
\hline $\mathrm{Th}_{0.76} \mathrm{U}_{0.24} \mathrm{O}_{2}$ & $10^{-4} \mathrm{M}$ & $-49.1 \pm 0.2$ & $-51.2 \pm 0.2$ & $\mathrm{Th}(\mathrm{OH})_{4}$ & $-47.8,-47.0$ & [16] \\
\hline $\mathrm{Th}_{0.33} \mathrm{U}_{0.67} \mathrm{O}_{2}$ & $\begin{array}{l}10^{-3} \mathrm{M} \\
10^{-2} \mathrm{M} \\
10^{-1} \mathrm{M}\end{array}$ & $\begin{array}{l}-49.3 \pm 0.2 \\
-51.2 \pm 0.2 \\
-54.1 \pm 0.2\end{array}$ & $\begin{array}{l}-51.4 \pm 0.2 \\
-53.3 \pm 0.2 \\
-56.3 \pm 0.2\end{array}$ & $\begin{array}{c}\mathrm{Th}(\mathrm{OH})_{4} \\
\mathrm{ThO}_{2} \cdot \mathrm{H}_{2} \mathrm{O} \\
\mathrm{ThO}_{2}\end{array}$ & $\begin{array}{c}47.8,47.0 \\
-53.2 \\
-54.2 \\
-56.9\end{array}$ & $\begin{array}{l}{[16]} \\
{[17]} \\
{[18]} \\
{[19]}\end{array}$ \\
\hline $\mathrm{Th}_{0.19} \mathrm{U}_{0.81} \mathrm{O}_{2}$ & $\begin{array}{l}10^{-3} \mathrm{M} \\
10^{-2} \mathrm{M} \\
10^{-1} \mathrm{M}\end{array}$ & $\begin{array}{l}-49.7 \pm 0.2 \\
-51.2 \pm 0.2 \\
-54.0 \pm 0.2\end{array}$ & $\begin{array}{l}-51.9 \pm 0.2 \\
-53.3 \pm 0.2 \\
-56.2 \pm 0.2\end{array}$ & $\begin{array}{c}\mathrm{Th}(\mathrm{OH})_{4} \\
\mathrm{ThO}_{2} \cdot \mathrm{H}_{2} \mathrm{O} \\
\mathrm{ThO}_{2}\end{array}$ & $\begin{array}{l}-47.8 \\
-53.2 \\
-54.2 \\
-56.9\end{array}$ & $\begin{array}{l}{[16]} \\
{[17]} \\
{[18]} \\
{[19]}\end{array}$ \\
\hline
\end{tabular}




\section{Figure captions}

Figure 1: Deconvolution of XPS spectra in the $\mathrm{U}_{4 \mathrm{f}}$ region for $\mathrm{Th}_{0.47} \mathrm{U}_{0.53} \mathrm{O}_{2}$ before leaching.

Figure 2: Deconvolution of XPS spectra in the $\mathrm{O}_{1 \mathrm{~s}}$ region for $\mathrm{Th}_{0.47} \mathrm{U}_{0.53} \mathrm{O}_{2}$ before leaching.

Figure 3: Evolution of the dissolved mass of Th and $U$ for $\mathrm{Th}_{0.63} \mathrm{U}_{0.37} \mathrm{O}_{2}, \mathrm{Th}_{0.47} \mathrm{U}_{0.53} \mathrm{O}_{2}$ and $\mathrm{Th}_{0.33} \mathrm{U}_{0.67} \mathrm{O}_{2}$ in several $\mathrm{HNO}_{3}$ concentrations. Full symbols correspond to $\mathrm{U}$ mass loss; empty symbols correspond to Th mass loss.

Figure 4: Variation of the normalized mass loss versus time square root for $\mathrm{Th}_{0.19} \mathrm{U}_{0.81} \mathrm{O}_{2}$. Full symbols correspond to U mass loss; empty symbols correspond to Th mass loss.

Figure 5: Variation of $\log \mathrm{R}_{\mathrm{H}}(\mathrm{U})$ versus $\log \mathrm{a}\left(\mathrm{H}_{3} \mathrm{O}^{+}\right)$for $\mathrm{Th}_{0.47} \mathrm{U}_{0.53} \mathrm{O}_{2}$ and $\mathrm{Th}_{0.33} \mathrm{U}_{0.67} \mathrm{O}_{2}$ and $\mathrm{Th}_{0.19} \mathrm{U}_{0.81} \mathrm{O}_{2}$.

Figure 6: XANES data for uranium $\mathrm{L}_{\text {III }}$ edge for $\mathrm{Th}_{0.76} \mathrm{U}_{0.24} \mathrm{O}_{2}$ and $\mathrm{Th}_{0.47} \mathrm{U}_{0.53} \mathrm{O}_{2}$ solid solutions leached in $10^{-1} \mathrm{M} \mathrm{HNO}_{3}$, compared to $\mathrm{UO}_{2}$ and $\mathrm{U}_{3} \mathrm{O}_{8}$ references.

Figure 7- Fourier transform of XAFS spectra for $\mathrm{Th}_{0.47} \mathrm{U}_{0.53} \mathrm{O}_{2}$ before leaching (upper), and $\mathrm{Th}_{0.47} \mathrm{U}_{0.53} \mathrm{O}_{2}$ leached at $\mathrm{pH}=11$ and $\mathrm{pH}=1$ (lower).

Figure 8- Deconvolution of XPS spectrum in the $\mathrm{O}_{1 \mathrm{~s}}$ region for $\mathrm{Th}_{0.19} \mathrm{U}_{0.81} \mathrm{O}_{2}$ leached in $10^{-1} \mathrm{M}$ $\mathrm{HNO}_{3}$ for 200 days.

Figure 9- Deconvolution of XPS spectrum in the $U-4 f_{7 / 2}$ spectra obtained for $T h_{0.19} U_{0.81} \mathrm{O}_{2}$ leached in $10^{-1} \mathrm{M} \mathrm{HNO}_{3}$ for 200 days. 


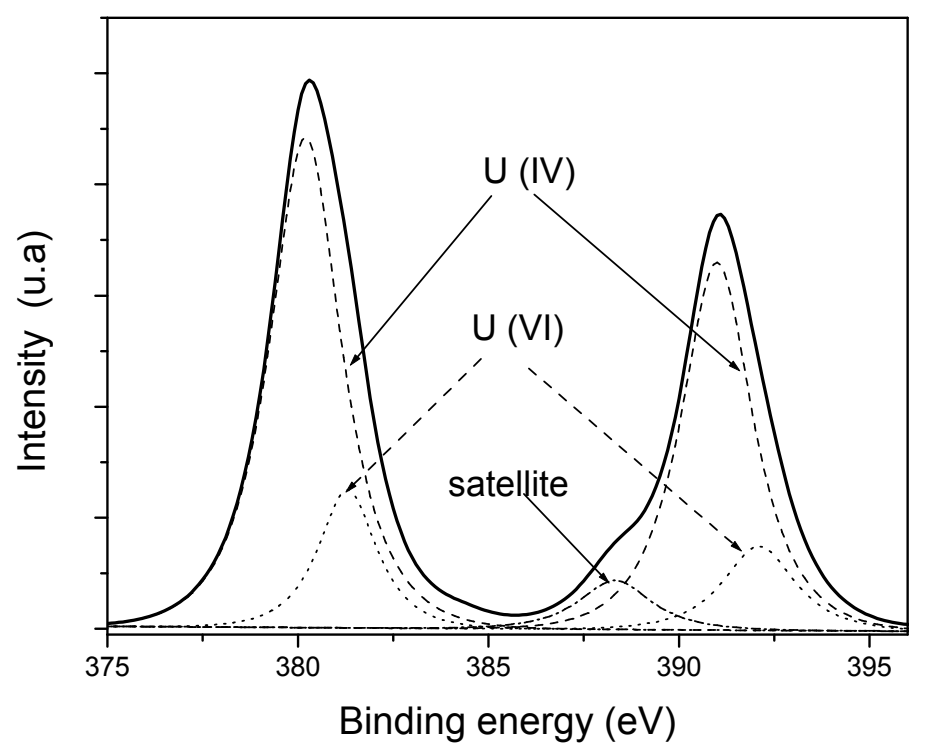

Fig. 1

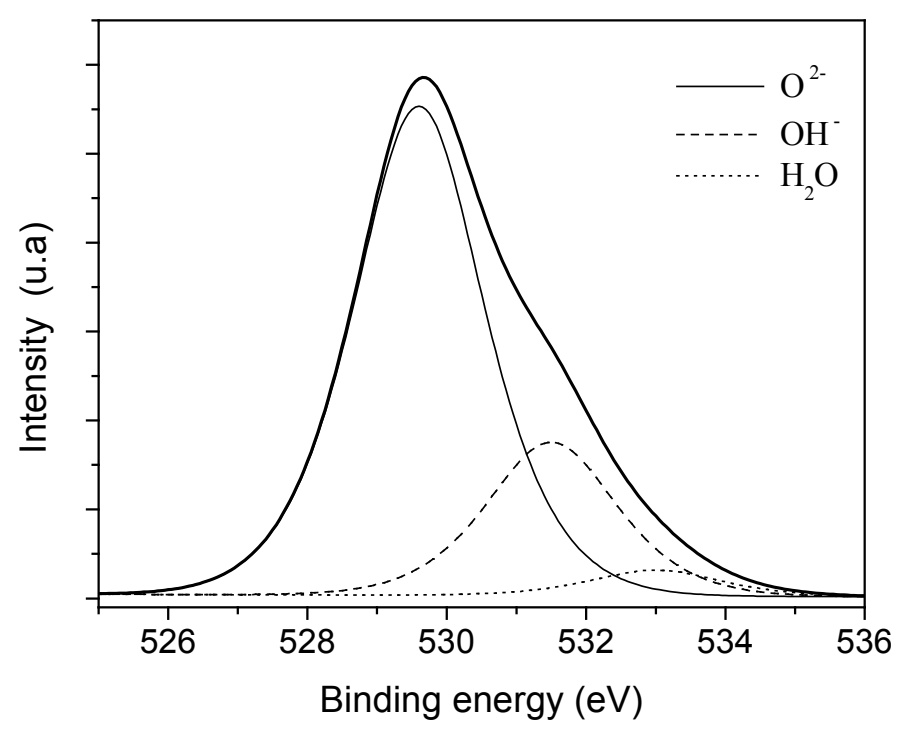

Fig. 2 

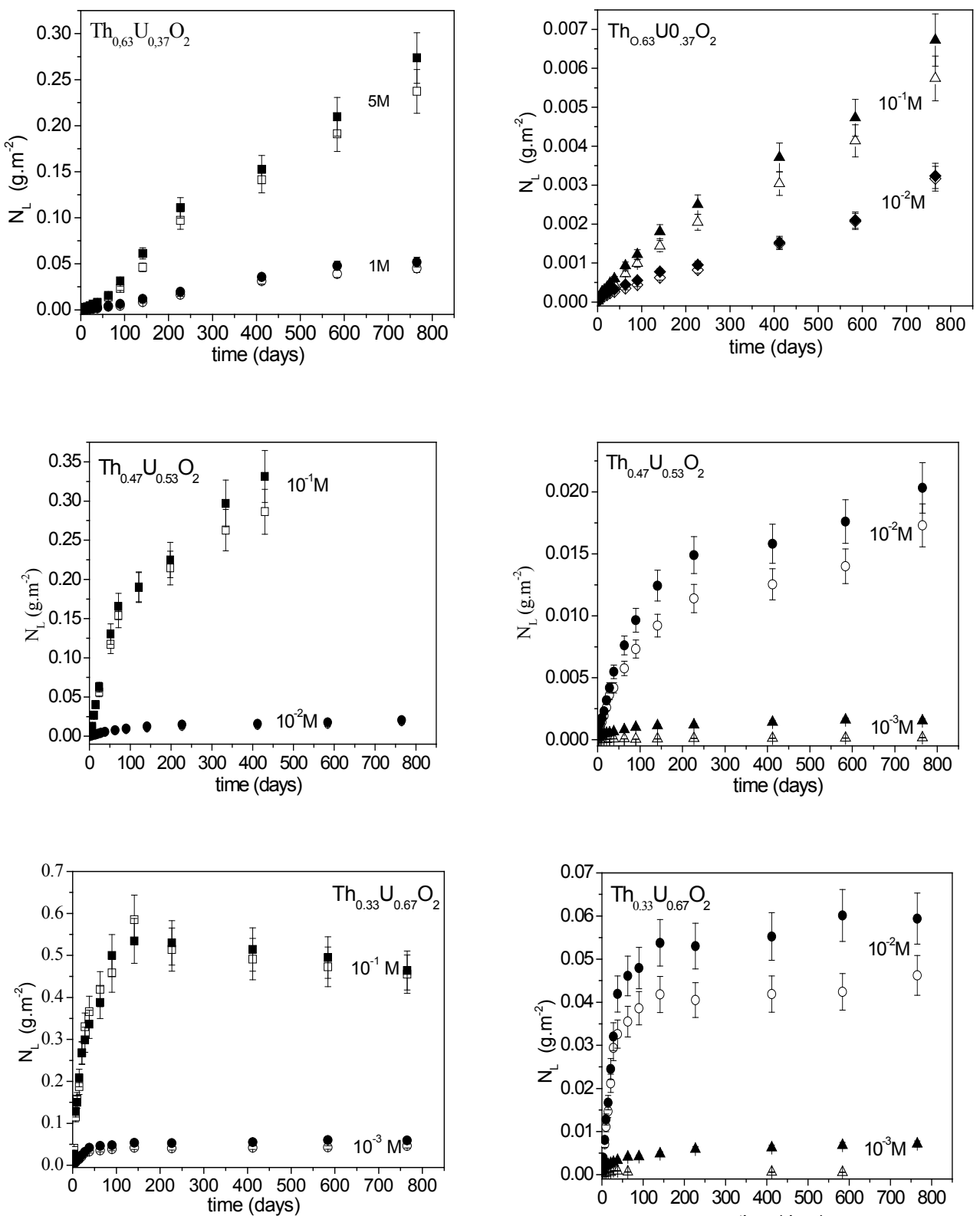

Fig. 3 


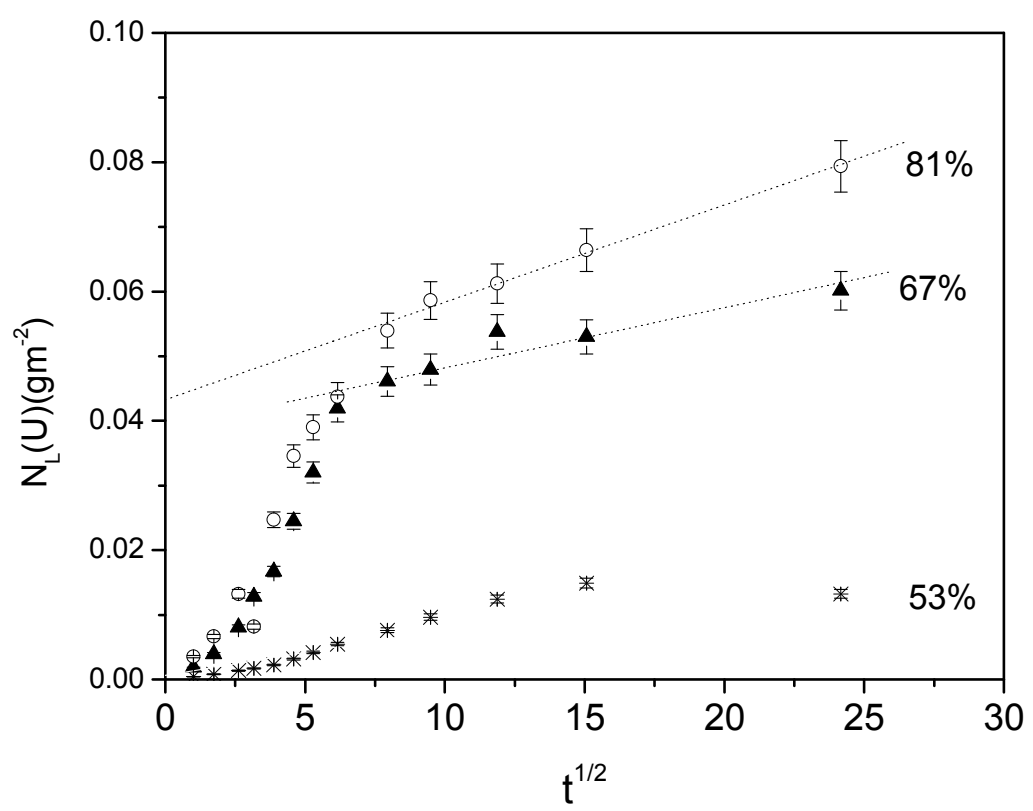

Fig. 4

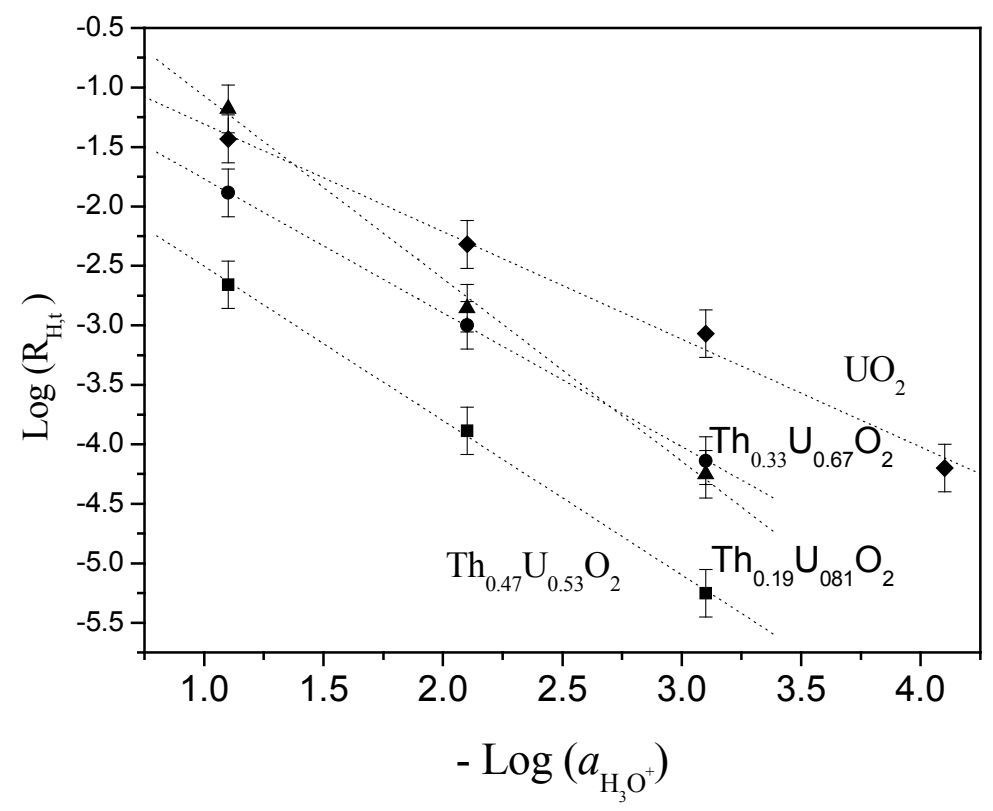

Fig. 5 


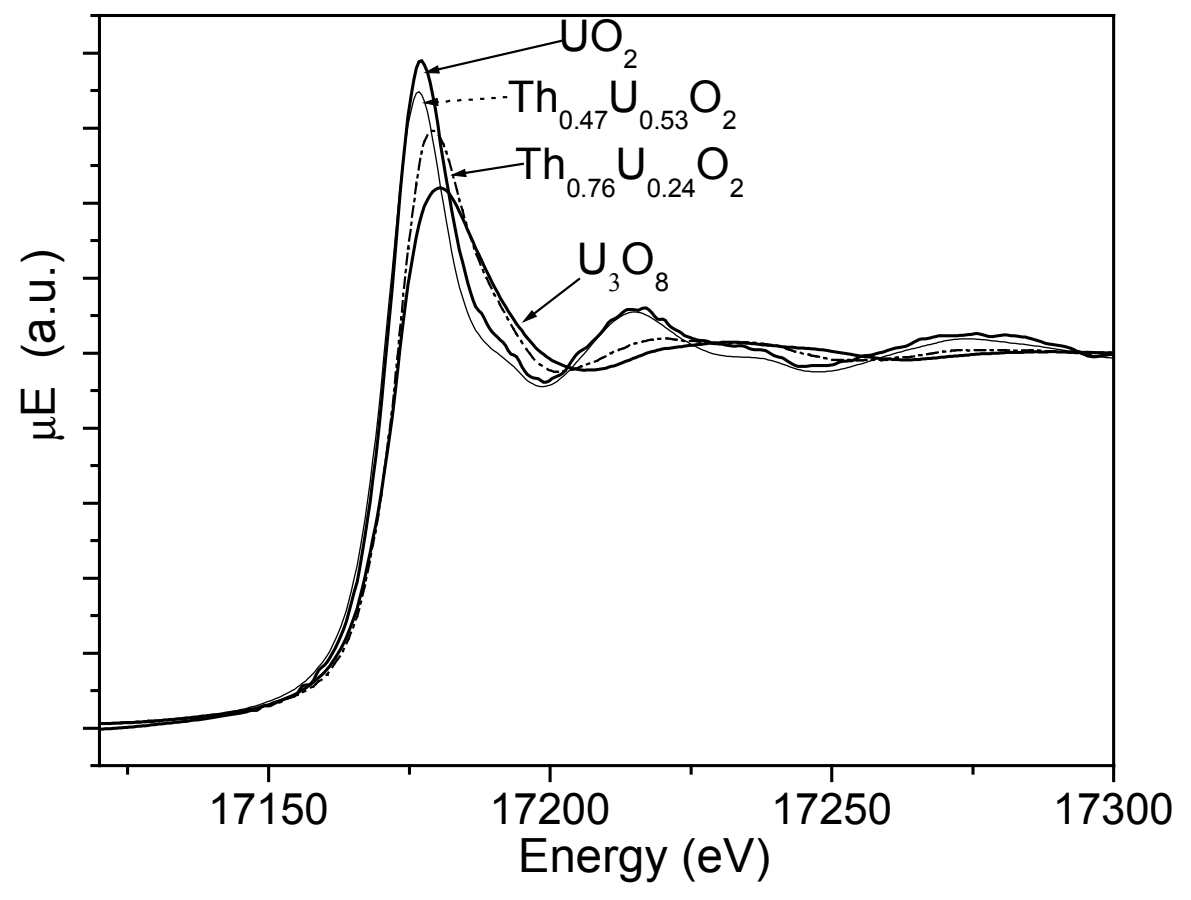

Fig. 6

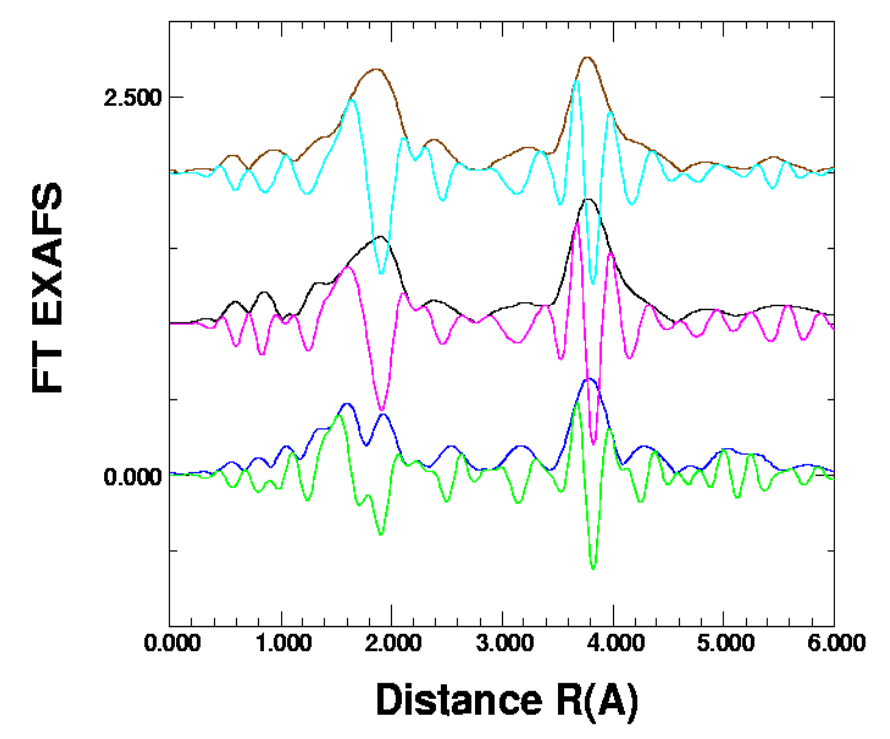

Fig. 7 


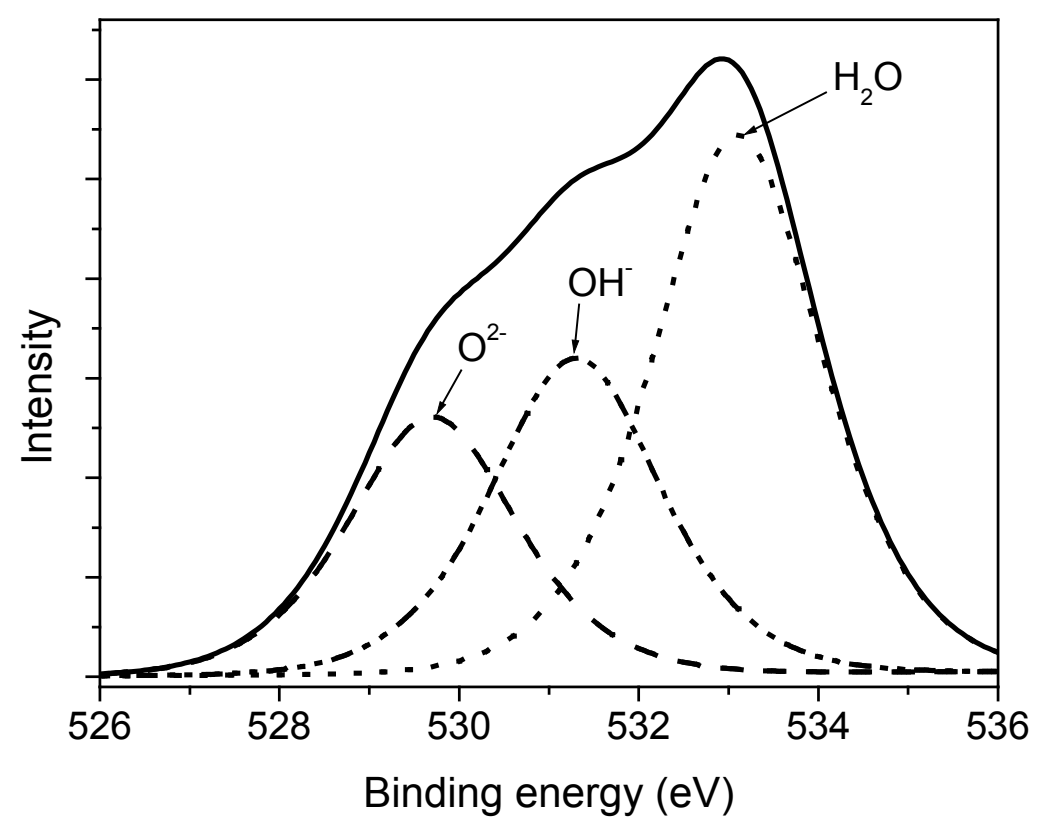

Fig. 8

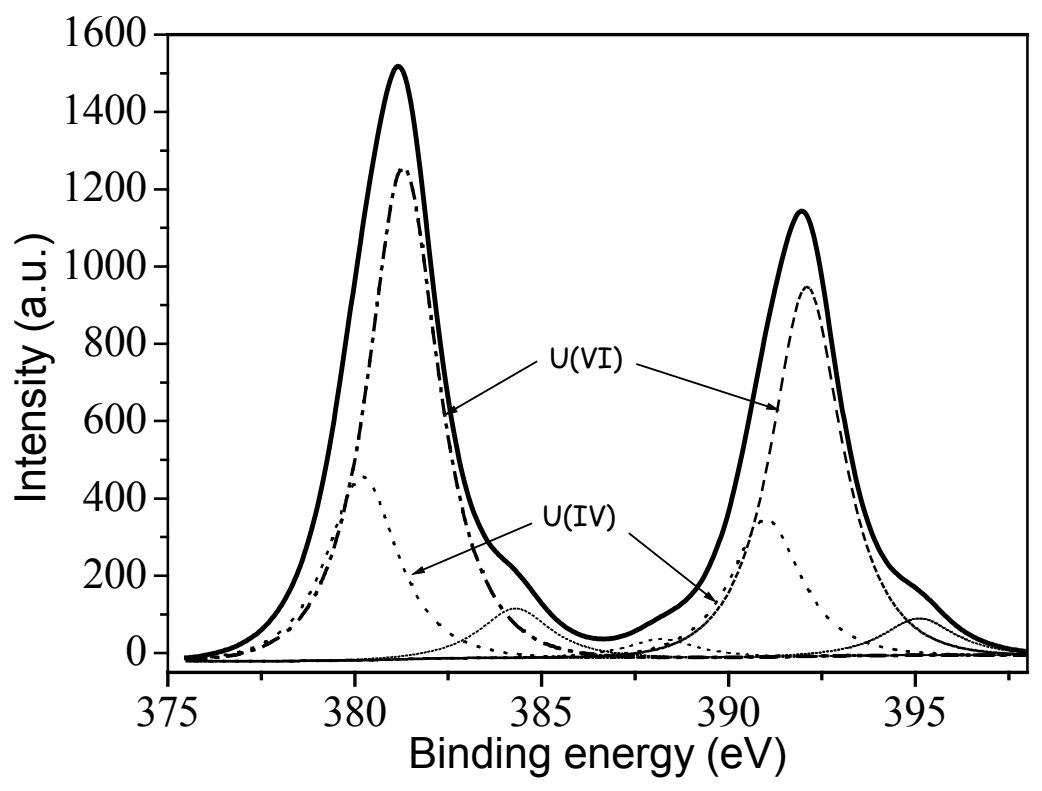

Fig. 9 